Article

\title{
Cloning, Expression, and Characterization of Thermotolerant Manganese Superoxide Dismutase from Bacillus sp. MHS47
}

\section{Supatra Areekit ${ }^{1}$, Pornpimon Kanjanavas ${ }^{2}$, Paisarn Khawsak ${ }^{1}$, Arda Pakpitchareon ${ }^{1}$, Kajeenart Potivejkul ${ }^{3}$, Gaysorn Chansiri ${ }^{4}$ and Kosum Chansiri ${ }^{1, *}$}

1 Department of Biochemistry, Faculty of Medicine, Srinakharinwirot University, Bangkok 10110, Thailand; E-Mails: jeedkha@hotmail.com (S.A.); pkhla@hotmail.com (P.K.); oom_arda@hotmail.com (A.P.)

2 Department of Biology, Faculty of Science and Technology, Rambhai Barni Rajabhat University, Chanthaburi 22000, Thailand; E-Mail: kanjanavas@hotmail.com

3 Department of Biology, Faculty of Science, Srinakharinwirot University, Bangkok 10110, Thailand; E-Mail:kajeenart@gmail.com

4 Department of Pharmaceutical Technology, Faculty of Pharmacy, Silpakorn University, Nakhon Pathom 73000, Thailand; E-Mail: gaysorn@email.pharm.su.ac.th

* Author to whom correspondence should be addressed; E-Mail: kchansiri@yahoo.com; Tel.: +662-664-1000(4605); Fax: +662-664-1000(4618).

Received: 20 December 2010; in revised form: 11 January 2011 / Accepted: 21 January 2011 / Published: 24 January 2011

\begin{abstract}
A superoxide dismutase gene from thermotolerant Bacillus sp. MHS47 (MnSOD47) was cloned, sequenced, and expressed. The gene has an open reading frame of $612 \mathrm{bp}$, corresponding to 203 deduced amino acids, with high homology to the amino acid sequences of $B$. thuringiensis (accession no. EEN01322), B. anthracis (accession no. NP_846724), B. cereus (accession no. ZP_04187911), B. weihenstephanensis (accession no. YP_001646918), and B. pseudomycoides. The conserved manganese-binding sites (H28, H83, D165, and H169) show that MnSOD47 has the specific characteristics of the manganese superoxide dismutase (MnSOD) enzymes. MnSOD47 expressed an enzyme with a molecular weight of approximately $22.65 \mathrm{kDa}$ and a specific activity of $3537.75 \mathrm{U} / \mathrm{mg}$. The enzyme is active in the $\mathrm{pH}$ range $7-8.5$, with an optimum $\mathrm{pH}$ of 7.5 , and at temperatures in the range $30-45^{\circ} \mathrm{C}$, with an optimum temperature of $37^{\circ} \mathrm{C}$. Tests of inhibitors and metal ions indicated that the enzyme activity is inhibited by sodium azide, but not by hydrogen peroxide or potassium cyanide. These data should benefit future
\end{abstract}


studies of MnSODs in other microorganisms and the biotechnological production of MnSOD47, and could also be used to develop a biosensor for the detection of antioxidants and free radical activity. In the future, this basic knowledge could be applicable to the detection of cancer risks in humans and therapeutic treatments.

Keywords: thermotolerant; MnSOD; cloning; expression; Bacillus sp.

\section{Introduction}

Superoxide dismutase (SOD) is a metabolic enzyme that specifically catalyzes the conversion of the superoxide radical $\left(\mathrm{O}^{2-}\right)$ to $\mathrm{H}_{2} \mathrm{O}_{2}$ and $\mathrm{O}_{2}$. SODs are considered key enzymes in the control of oxidative stress because they can protect oxygen-metabolizing cells against the harmful effects of superoxide free radicals [1-4]. The SOD metalloenzymes can be separated into three classes based on the metal cofactors at their active sites: copper/zinc SOD (Cu/ZnSOD), manganese SOD (MnSOD), and iron SOD (FeSOD) [5,6].

Recently, SODs have been used in gene therapy and therapeutic treatments for oxidative damage in the treatment of postischemic reperfusion injury, rheumatoid arthritis and osteoarthritis, brain trauma, influenza-induced lung pneumonitis, breast cancer, nervous system dysfunction, persistent pulmonary hypertension, and tissue damage. SODs are considered to be clinically useful for a wide variety of applications, including the prevention of oncogenesis, tumor promotion, and tumor invasiveness, and the reduction of the cytotoxic and cardiotoxic effects of anticancer drugs [7-17]. A SOD biosensor has also been used to determine the antioxidant properties of acetylsalicylic-acid-based drugs and the antiradical activity of healthy and cancerous human brain tissues [18].

Today, thermostable enzymes play important roles in industry because of their stability. Among these, thermostable SODs from thermotolerant or thermophilic microorganisms have received increasing attention [19]. SODs have been isolated from hyperthermophiles of the genera Sulfolobus and Pyrobaculum, and from Aquifex pyrophilus, Thermothrix sp., and Rhodothermus sp. [20-25].

In this study, we focused on the isolation and characterization of the gene encoding SOD in the thermotolerant microorganism Bacillus sp. MHS47, which was isolated from hot springs. The SOD gene and its expression were investigated. Our results should facilitate its use in pharmaceutical and medical research, and its biotechnological production.

\section{Results and Discussion}

\subsection{Isolation of the Bacillus sp. MHS47}

Soil and water samples from hot springs in Mae Hong Son Province of Thailand were previously collected and screened for thermotolerant bacteria using a dilution technique, and were cultured at $45{ }^{\circ} \mathrm{C}$. Isolate MHS47 is a Gram-positive, rod-shaped aerobic bacterium. It was identified by $16 \mathrm{~S}$ ribosomal DNA (rDNA) analysis and this sequence was deposited in GenBank under accession number HQ166833. Comparison of its nucleotide sequence revealed that the isolate was $99 \%$ homologous to B. cereus. 


\subsection{Expression and Purification of $\mathrm{MnSOD} 47$}

The gene encoding MnSOD (MnSOD47) was amplified from the genomic DNA of Bacillus sp. MHS47, using primers designed to Bacillus spp. The SOD gene sequences have been submitted to GenBank, as indicated in the Experimental Section. PCR amplification generated a product of $612 \mathrm{bp}$. The fragment was ligated and cloned, and three positively transformed colonies were selected. The nucleotide sequence confirmed that the complete MnSOD47 gene is 612 bp long (accession number HQ112282), corresponding to 204 deduced amino acids, with a molecular weight (MW) of approximately $22.65 \mathrm{kDa}$ and a $\mathrm{pI}$ of 5.31 (Figure 1).

Figure 1. SDS-PAGE profile of the purified recombinant MnSOD47 enzyme. Lanes: M, standard protein marker; 1, MnSOD47 before induction with IPTG; 2, MnSOD47 after induction with $0.5 \mathrm{mM}$ IPTG; 3, Purified MnSOD47. Visualized by Coomassie-Blue-staining.

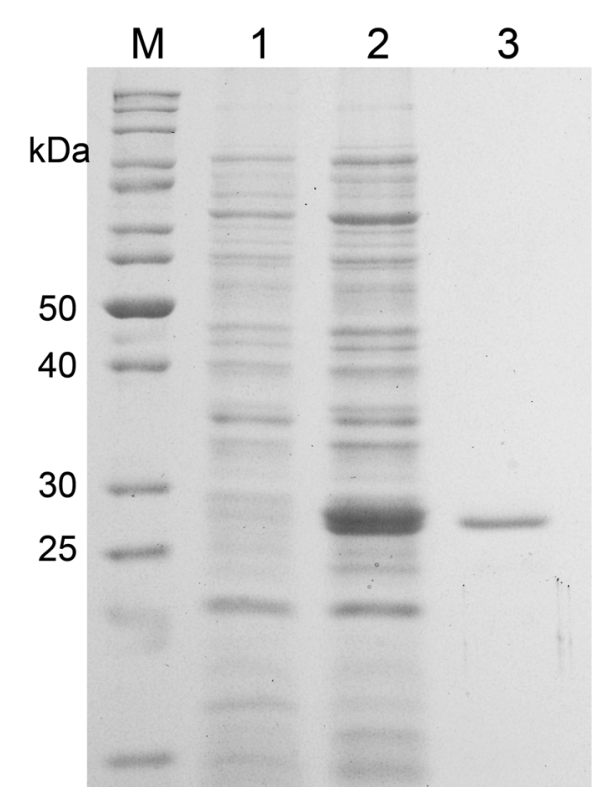

An amino acid comparison of the active site and the conserved and semiconserved regions indicated that the MnSOD47 enzyme is similar to those regions of B. cereus AH1271, with 99\% homology. The four residues of the enzyme that are putatively essential to coordinate the single trivalent manganese (H28, H83, D165, H169; Figure 2) are conserved, as they are similarly conserved in other reported MnSODs [26]. MnSOD47 also contains the decapod crustacean signature (DXWEHXXY), which is a specific characteristic of MnSOD [27]. Western blot analysis of MnSOD47 probed with rabbit anti-Cu/Zn SOD antibody confirmed that the enzyme is a SOD (Figure 3). The specific activity of the purified enzyme was $3537.75 \mathrm{U} / \mathrm{mg}$, with a protein recovery of $54.3 \%$ and 14 -fold purification (Table 1). 
Figure 2. Alignment of the amino acid sequence of MnSOD47 with those of other bacterial MnSODs: B. licheniformis (B1, accession no. YP_079829); B. subtilis (Bs, accession no. $\mathrm{ZP}$ _03592273); B. thuringiensis (Bt, accession no. EEN01322); B. anthracis (Ba, accession no. NP_846724); B. cereus (Bc, accession no. ZP_04187911); B. weihenstephanensis (Bw, accession no. YP_001646918); B. pseudomycoides (Bps, accession no. ZP_04152942); Anoxybacillus flavithermus (Af, accession no. YP_ 002315239); and Listeria monocytogenes (Lm, accession no. YP_ 079829). The residues highlighted in dark gray represent the four metal-binding sites, which coordinate the metal ion. These residues are conserved in all reported FeSODs and MnSODs. The amino acids characteristic of the MnSODs are boxed [28,29]. The MnSOD signature of the decapod crustaceans (DXWEHXXY) is underlined.

\begin{tabular}{|c|c|}
\hline (Mn) & -MAYKLPELPYAYDALEPHIDKETMNIHHTKHHNTYVTKLNEAVAGKQDLESKSVEELVA \\
\hline (Mn) & -MAYELPELPYAYDALEPHIDKETMPIHHTKHHNTYVTNLNKAVEGNTALANKSVEELVA \\
\hline (Mn) & MAKHELPNLPYAYDALEPHFDKETMHIHHTKHHNTYITNLNAALEGHAELADKSVEELVA \\
\hline (Mn) & MAKHELPNLPYAYDALEPHFDKETMNIHHTKHHNTYITNLNAALEGHAELADKSVEELVA \\
\hline (Mn) & MAKHELPNLPYAYDALEPHFDKETMNIHHTKHHNTYITNLNAALEGHAELADKSVEELVA \\
\hline MnSOD 47 & MAKHELPNLPYAYDALEPHFDKETMNIHHTKHHNTYITNLNAALEGHAELADKSVEELVA \\
\hline $\mathrm{BW}(\mathrm{Mn})$ & MAKHELPNLPYAYDALEPHFDKETMNIHHTKHHNTYITNLNAALEGHAELADKSVEELVA \\
\hline Bps (Mn) & MAKHELPNLPYAYDALEPHFDKETMHIHHTKHHNTYVTNLNAALEGHAELADKSVEELVA \\
\hline Af $(\mathrm{Mn})$ & -MAFELPQLPYAYDALEPHIDKETMNIHHTKHHNAYVTNLNAALEGHPELQSKTIEELMA \\
\hline$(\mathrm{Mn})$ & 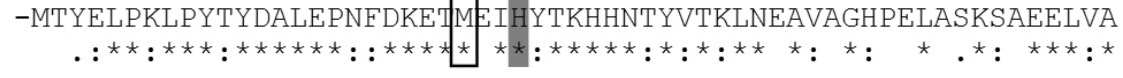 \\
\hline (Mn) & NLDAVPENIRTAVRNNGGGHANHSLFWKLLSPNGGGAPTGELAEAINSKFGSFDQFKEDF \\
\hline$(\mathrm{Mn})$ & FWTLLSPNGGGEPTGALAEEINSVFGSFDKFKEQF \\
\hline$(\mathrm{Mn})$ & NLNEVPEAIRTAVRNNGGGHANHTFFWTILSPNGGGQPVGELATAIEAKFGSFDAFKEEF \\
\hline$(\mathrm{Mn})$ & FWTILSPNGGGQPVGELATAIEAKFGSFDAFKEEF \\
\hline (Mn) & NLNEVPEAIRTAVRNNGGG|HANHTFFWTILSPNGGGQPVGELATAIEAKFGSFDAFKEEF \\
\hline MnSOD 47 & NLNEVPEAIRTAVRNNGGG|HANHTLFWTILSPNGGGQPVGELATAIEAKFGSFDAFKEEF \\
\hline $\mathrm{Bw}(\mathrm{Mn})$ & NLNEVPEAIRTAVRNNGGGHANHTFFWTILSPNGGGQPVGELATAIEAKFGSFDAFKAEF \\
\hline Bps (Mn) & NLNEVPEAIRTAVRNNGGGHANHTFFWTILSSNGGGQPVGELAAAIEAKFGSFDAFKTEF \\
\hline$(\mathrm{Mn})$ & HLNEVPENIRTAVRNNGGGHANHSLFWTILSPNGGGEPTGELAEAINNTFGSFEKFKEEF \\
\hline (Mn) & 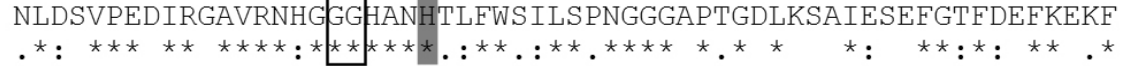 \\
\hline
\end{tabular}

B1 (Mn)

Bs (Mn)

Bt (Mn)

$\mathrm{Ba}(\mathrm{Mn})$

BC (Mn)

MnSOD 47

$\mathrm{Bw}$ (Mn)

Bps (Mn)

Af (Mn)

Lm (Mn)

Bl (Mn)

Bs (Mn)

Bt (Mn)

$\mathrm{Ba}(\mathrm{Mn})$

$\mathrm{BC}(\mathrm{Mn})$

MnSOD 47

$\mathrm{Bw}$ (Mn)

Bps (Mn)

Af (Mn)

Lm (Mn)

AAAAAGRFGSGWAWLVVNNGELEITSTPNQDSPLSEGKTPILGLDVWEHAYYLNYQNRRP 179 AAAAAGRFGSGWAWLVVNNGKLEITSTPNQDSPLSEGKTP ILGLDVWEHAYYLNYQNRRP 179 AKAGATRFGSGWAWLVVNNGELEVTSTPNQDSSPLTEGKTPVIGLDVWEHAYYLNYQNRRP 180 AKAGATRFGSGWAWLVVNNGELEVTSTPNQDSPLTEGKTPVIGLDVWEHAYYLNYQNRRP 180 AKAGATRFGSGWAWLVVNNGELEVTSTPNQDSPLTEGKTPVVGLDVWEHAYYLNYQNRRP 180 AKAGATRFGSGWAWLVVNNGELEVTSTPNQDSPLTEGKTPVIGLDVWEHAYYLNYQNRRP 180 AKAGATRFGSGWAWLVVNNGELEVTSTPNQDSPLTEGKTPVIGLDVWEHAYYLNYQNRRP 180 AKAGATRFGSGWAWLVVNNGELEVTSTPNQDSSPLTEGKTPVIGLDVWEHAYYLHYQNRRP 180 SKAAATRFGSGWAWLVVHNGQLEVTSTPNQDTPLMEGKTPILGLDVWEHAYYLKYQNRRP 179 NAAAAARFGSGWAWLVVNNGKLEIVSTANQDSPLSDGKTPVLGLDVWE HAYYLKFQNRRP 179

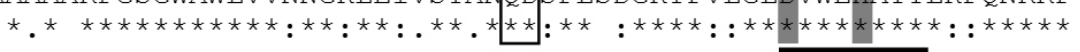

DYIKAFWNVNNWDEVARLYSEAK 202 DYISAFWNVVNWDEVARLYSEAK 202 DYIGAFWNVWDWNAAEKRYQQAK 203 DYIGAFWNVJDWNAAEKRYQEAK 203 DYIGAFWNVNDWNAAEKRYQEAK 203 DYIGAFWNVJDWNAAEKRYQEAK 203 DYIGAFWNVVDWNVAEKLYQEAK 203 DYIGAFWN VVDWNAAEKRYQEAK 203 DYISAFWN VNNWDEVAKRYAAAK 202 EYIDTFWNVINWDEANKRFDTAK 202 $: * \star: * \star \star \star:: *: .: \quad: * \star$ 
Figure 3. Western blot analysis of MnSOD probed with rabbit anti-Cu/Zn SOD antibody. Lanes: M, standard protein marker; 1, MnSOD.

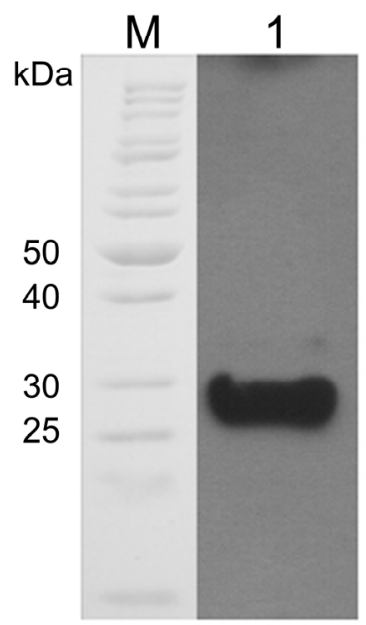

Table 1. Purification of MnSOD47.

\begin{tabular}{|c|c|c|c|c|c|c|}
\hline Purification & $\begin{array}{c}\text { Total Volume } \\
\text { (mL) }\end{array}$ & $\begin{array}{c}\text { Total } \\
\text { Protein (mg) }\end{array}$ & $\begin{array}{c}\text { Total } \\
\text { Activity (U) }\end{array}$ & $\begin{array}{c}\text { Specific } \\
\text { Activity (U/mg) }\end{array}$ & $\begin{array}{c}\text { Protein } \\
\text { Recovery (\%) }\end{array}$ & $\begin{array}{c}\text { Purification } \\
\text { (fold) }\end{array}$ \\
\hline $\begin{array}{c}\text { Crude Extract } \\
\text { Non-Induce }\end{array}$ & 25 & 15.31 & 1701 & 111.10 & - & - \\
\hline $\begin{array}{c}\text { Crude Extract } \\
\text { Induce }\end{array}$ & 25 & 14.77 & 3648 & 252.13 & 100 & 1 \\
\hline Ni-NTA & 4.5 & 0.56 & 1981 & 3537.75 & 54.3 & 14 \\
\hline
\end{tabular}

\subsection{Effect of $p H$ and Temperature on MnSOD47 Activity}

The effect of $\mathrm{pH}$ and temperature on the enzyme activity of MnSOD47 and the kinetics of its thermostability are shown in Figure 4. The enzyme is active in the $\mathrm{pH}$ range 7-8.5, with an optimum at $\mathrm{pH} 7.5$ (Figure 4A) and in the temperature range of $30-45^{\circ} \mathrm{C}$, with an optimum at $37{ }^{\circ} \mathrm{C}$ (Figure 4B). The temperature stability test showed that $50 \%$ activity was retained after its incubation at $45{ }^{\circ} \mathrm{C}$ for 40 min (Figure 5).

Figure 4. Effect of (A) pH, and (B) temperature on the enzymatic activity of MnSOD47.

(A)

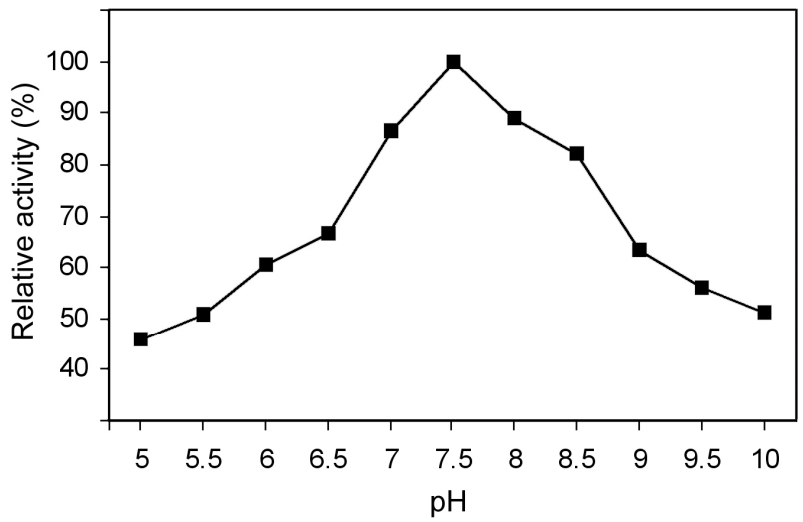

(B)

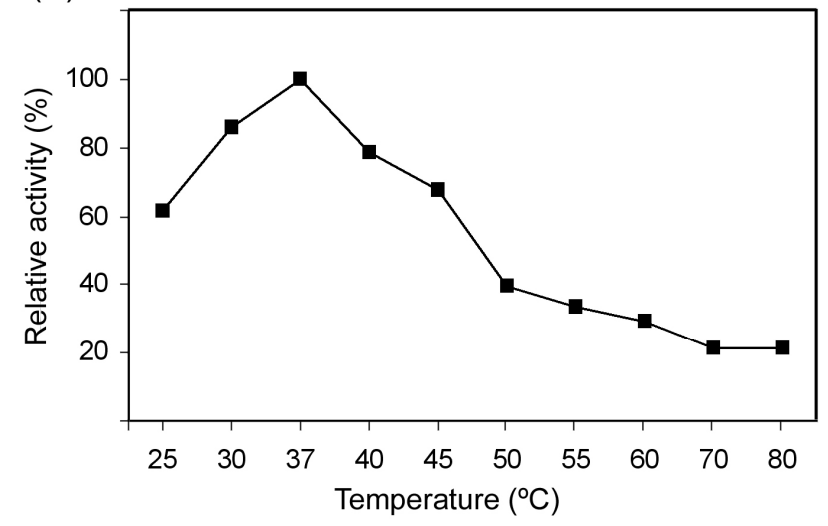


Figure 5. Thermostability of MnSOD47 activity.

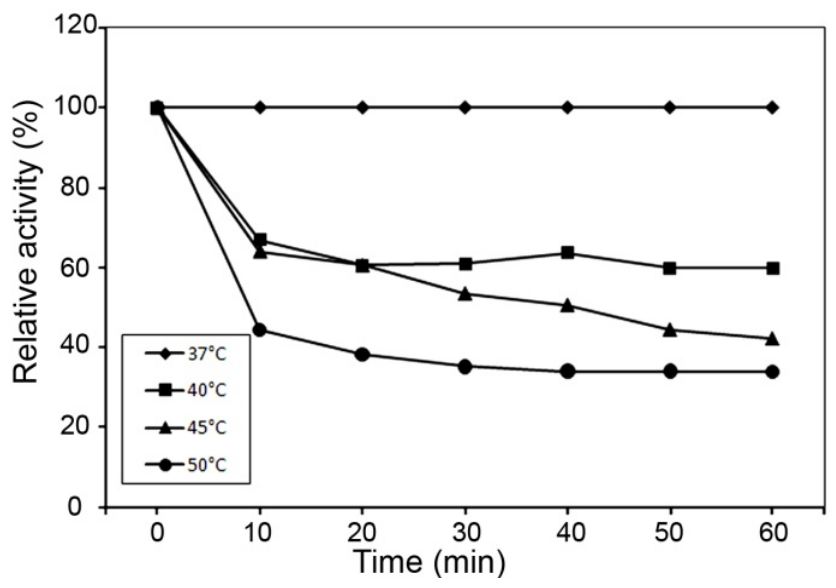

\subsection{Effect of Inhibitors on MnSOD47 Activity}

The enzyme's activity was inhibited by sodium azide $\left(\mathrm{NaN}_{3}\right)$, but not by hydrogen peroxide $\left(\mathrm{H}_{2} \mathrm{O}_{2}\right)$ or potassium cyanide $(\mathrm{KCN})$. Figure 6 shows the effects of the inhibitors on MnSOD47 activity, demonstrated with $12.5 \%$ native polyacrylamide gel electrophoresis. The inhibition of MnSOD47 activity in the presence of $\mathrm{NaN}_{3}$ indicates that the enzyme is MnSOD.

Figure 6. Activity staining of MnSOD47 in the presence of various inhibitors. The zymogram was produced with $12.5 \%$ native polyacrylamide gel electrophoresis. Lane 1: stained protein; lane 2: with no inhibitor; lane 3: with $10 \mathrm{mM} \mathrm{KCN}$; lane 4: with $10 \mathrm{mM} \mathrm{H}_{2} \mathrm{O}_{2}$; lane 5: with $10 \mathrm{mM} \mathrm{NaN}_{3}$.

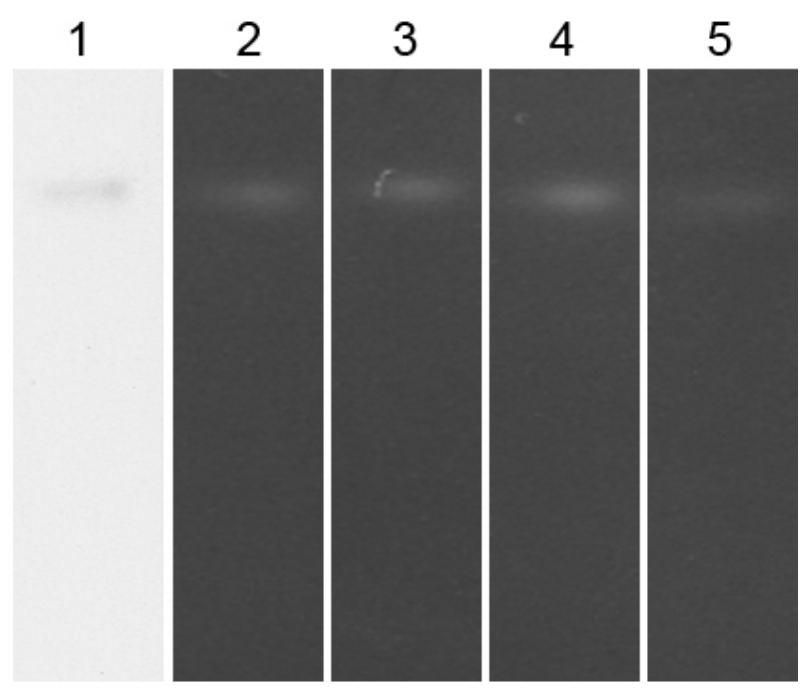

\subsection{Discussion}

In this study, the complete MnSOD47 gene was cloned and its nucleotide sequence was analyzed. The 204 deduced amino acids corresponded to a calculated monomeric MW of $22.65 \mathrm{kDa}$, similar to those of the MnSODs in B. thuringiensis (accession no. EEN01322), B. anthracis (accession No. NP_846724), B. cereus (accession no. ZP_04187911), B. weihenstephanensis (accession 
No. YP_001646918), and B. pseudomycoides (accession no. ZP_04152942). The most frequently reported molecular weights for the MnSODs range from 20 to $40 \mathrm{kDa}$ [30]. The theoretical isoelectric point (pI) of the protein was calculated to be 5.31, which is in the range of known SOD pI values of 4.0-6.0 [31]. SDS-PAGE analysis showed that the molecular mass of MnSOD47 was approximately $27 \mathrm{kDa}$, which is higher than the calculated molecular mass. This effect is attributed to the addition of a polyhistidine tag at the 5' end of the recombinant sequence [32]. According to the characteristics of the MnSOD47 amino acid sequence, the enzyme shares the features conserved in the SODs, including the manganese-binding site, which consists of three histidines and one aspartate residue (H28, H83, H169, and D165) [26]. In addition to the metal ligands, a number of other residues are strictly conserved, including an aspartic acid residue (D165, according to MnSOD47 sequence numbering) that is part of the distinctive DXWEHXXY sequence motif, which contains two of the four proteindonated metal ligands (E168 and H169). The cysteine residues that are inferred to form an intrasubunit disulfide bridge in other SODs are absent. The specific activity of the purified enzyme is $3537.75 \mathrm{U} / \mathrm{mg}$. This value is higher than those of the MnSOD activities reported for Thermus aquaticus [33] and Haliotis discus [31], but lower than the unusually stable MnSOD reported from Tatumella ptyseos [34]. The optimum $\mathrm{pH}$ and optimum temperature for MnSOD47 activity are similar to those of MnSOD from the disk abalone (Haliotis discus discus), which was cloned and expressed in Escherichia coli $\mathrm{K} 12$ (TB1) [31] and has an optimum temperature of $37^{\circ} \mathrm{C}$. The enzymatic activity of MnSOD47 is inhibited by $\mathrm{NaN}_{3}$, but not by $\mathrm{H}_{2} \mathrm{O}_{2}$ or $\mathrm{KCN}$, indicating that the enzyme is MnSOD [1,19,35,36].

\section{Experimental Section}

\subsection{Bacterial Strain Collection}

A thermotolerant Bacillus was isolated from hot spring water in the Mae Hong Son Province of Thailand. Soil and water samples had previously been screened for bacterial strains using a dilution technique, cultured in Luria-Bertani (LB) broth at $45^{\circ} \mathrm{C}$ for $24 \mathrm{~h}$, and were then cross-streaked on LB agar. Pure single colonies were transferred to an LB slant for stock culture. The purified colony was identified using the $\mathrm{API}^{\circledR} 50 \mathrm{CH}$ Kit (BioMerieux, Lyon, France) and 16S rDNA nucleotide sequence analysis.

\subsection{Genomic DNA Extraction}

The selected Bacillus isolate with the highest production of SOD was cultured in LB medium at $45^{\circ} \mathrm{C}$ for $12-14 \mathrm{~h}$. The genomic DNA was extracted from Bacillus sp. MHS47 using a genomic DNA Purification Kit (Gentra Systems, Minneapolis, USA). The DNA pellet was dissolved in TE buffer and stored at $4{ }^{\circ} \mathrm{C}$.

\subsection{PCR Amplification of the $16 \mathrm{~S} r D N A$}

PCR amplification was performed using specific universal primers for bacterial $16 \mathrm{~S}$ rDNA (8F 5'-AGAGTTTGATCCTGGCTCAG-3' and 1492R 5'-ACGGTTACCTTGTTACGACTT-3') [37]. All the reactions were manipulated in $25 \mu \mathrm{L}$ volumes containing $50 \mathrm{ng}$ of genomic DNA in $10 \times$ PCR 
buffer, $1 \mu \mathrm{M}$ each primer, $100 \mu \mathrm{M}$ dNTP, $1.5 \mathrm{mM} \mathrm{MgCl}_{2}$, and $1.5 \mathrm{U}$ of proofreading Taq DNA polymerase $\left(\right.$ Invitrogen $^{\circledR}$ ). PCR was performed in a DNA thermal cycler (MJ Research PTC-200 Peltier) for 30 cycles. Each cycle consisted of denaturation at $94{ }^{\circ} \mathrm{C}$ for $1 \mathrm{~min}$, annealing at $54{ }^{\circ} \mathrm{C}$ for $1 \mathrm{~min}$, and extension at $72{ }^{\circ} \mathrm{C}$ for $1 \mathrm{~min}$.

\subsection{PCR Amplification of the MnSOD Gene from Bacillus sp. MHS47}

The MnSOD47 gene was PCR amplified using SOD primers designed for Bacillus spp. (accession numbers AE016879, AE017194, AE017225, AE017355, AE017334, CP000001, and CP000485). A CACC sequence was added to the 5 ' end of the forward primer, followed by the nucleotide sequence specific for MnSOD47. The forward and reverse primers (SOD-BacillusF and SOD-BacillusR) were 5'-CACCATGGCAAAACACGAATT-3' and 5'-TTATTTTGCTTCTTGGTAACG-3', respectively. The set of primers was synthesized by Invitrogen ${ }^{\circledR}$. All the reactions were performed in $25 \mu \mathrm{L}$ volumes containing $100 \mathrm{ng}$ of genomic DNA in $10 \times$ PCR buffer, $20 \mu \mathrm{M}$ each primer, $10 \mu \mathrm{M}$ dNTPs, $1.5 \mathrm{mM}$ $\mathrm{MgCl}_{2}$, and $1.5 \mathrm{U}$ of proofreading Taq DNA polymerase (Invitrogen ${ }^{\circledR}$ ). The PCR was performed using a DNA thermal cycler for 30 cycles. Each cycle consisted of denaturation at $94{ }^{\circ} \mathrm{C}$ for 1 min, annealing at $45{ }^{\circ} \mathrm{C}$ for $1 \mathrm{~min}$, and extension at $72{ }^{\circ} \mathrm{C}$ for $1 \mathrm{~min}$. The PCR fragment was analyzed by electrophoresis on a 1.2\% agarose gel. The PCR product was eluted from the gel and purified using the QIAquick $^{\circledR}$ gel extraction kit (Qiagen, Hilden, Germany) before it was cloned.

\subsection{Cloning the PCR Fragment}

The purified PCR fragment was ligated to the pET 100/D TOPO ${ }^{\circledR}$ vector using the Champion ${ }^{\mathrm{TM}}$ pET Directional TOPO ${ }^{\circledR}$ Expression Kit (Invitrogen ${ }^{\circledR}$ ). The reaction was performed according to the protocol provided by the manufacturer. White colonies containing recombinant DNA were selected and cultured in $5 \mathrm{~mL}$ of LB medium in the presence of $100 \mathrm{mg} / \mathrm{L}$ ampicillin for $24 \mathrm{~h}$.

\subsection{DNA Sequencing of the SOD Gene}

Recombinant plasmids containing the MnSOD47 gene were purified using the Qiagen ${ }^{\circledR}$ QIAprep Spin Miniprep Kit and sequenced in both directions using the BigDye Terminator Cycle Sequencing Kit (Macrogen, Korea). The nucleotide and amino acid sequences were analyzed with the BLAST program at http://www.ncbi.nlm.nih.gov/BLAST.

\subsection{Transformation and Expression of the MnSOD47 Gene}

The recombinant DNA was transformed into E. coli BL21 StarTM (DE3) One Shot ${ }^{\circledR}$ cells. The transformation was performed according to the protocol provided by the manufacturer. The recombinant cells were grown in $500 \mathrm{~mL}$ of LB containing $50 \mu \mathrm{L} / \mathrm{mL}$ ampicillin and $1 \%$ glucose at $37{ }^{\circ} \mathrm{C}$ until an optical density of 0.5 at $600 \mathrm{~nm}$ was reached. IPTG was added to a final concentration of $1 \mathrm{mM}$ and the samples were incubated for $6 \mathrm{~h}$. 


\subsection{Purification of the MnSOD47 Enzyme}

The MnSOD47 protein was purified as the polyhistidine-tagged recombinant protein on Protino ${ }^{\circledR}$ Ni-TED resin (Macherey-Nagel, Germany) under nondenaturing conditions. The protocol used was provided by the manufacturer. The eluted fractions were stored at $4{ }^{\circ} \mathrm{C}$ before their analysis by SDS-PAGE.

\section{9. $S D S-P A G E$}

Traditional SDS-PAGE was performed on a $12.5 \%$ separating gel to confirm the purified and apparent MW of the SOD enzyme, with Tris-glycine (pH 8.3) as the buffer [38].

\subsection{Protein Assay}

Protein concentrations were determined with the Bradford Protein Assay (Fermentas, USA), using bovine serum albumin as the standard, with the absorbance measured at $595 \mathrm{~nm}$.

\subsection{Immunoblotting Analysis}

Immunoblotting analysis was performed with the ECL Western blotting analysis system (Santa Cruz Biotechnology). SDS-PAGE was performed as described above. The proteins were blotted onto a sheet of polyvinylidene difluoride transfer membrane (Pall Life Science, Pensacola, FL), according to the instructions of the manufacturer. After blotting, the membrane was blocked by incubation with 5\% skim milk and PBS buffer ( $\mathrm{pH} 7.5$ ) for $2 \mathrm{~h}$ at room temperature. The blocked membrane was incubated at $4{ }^{\circ} \mathrm{C}$ for a further $12 \mathrm{~h}$ with primary anti-SOD1 antibody (rabbit polyclonal; 1:1000 dilution) before it was washed in TPBS (PBS buffer [pH 7.5] and 0.15\% Tween 20) for $1 \mathrm{~h}$ at room temperature. The membrane was then incubated with horseradish peroxidase (HRP)-conjugated goat anti-rabbit IgG antibody and the HRP-streptavidin complex for $1 \mathrm{~h}$ at room temperature. After repeated washing with TPBS buffer for $1 \mathrm{~h}$ at $4{ }^{\circ} \mathrm{C}$, the membrane was incubated with ECL detection reagent (SuperSignal West Pico, Rockfort, USA), before visualization with autoradiography.

\subsection{Enzyme Assay}

The activity of the purified recombinant MnSOD47 was determined with a Chemical SOD Assay Kit (Cayman, USA). The absorbance was measured at $450 \mathrm{~nm}$ with a spectrophotometer, using a xanthine oxidase/hypoxanthine generating system coupled to a tetrazolium salt to detect the reduction in superoxide radicals.

\subsection{Effect of $p H$ and Temperature on MnSOD47 Activity}

The optimum $\mathrm{pH}$ was determined in the presence of various buffer systems in the $\mathrm{pH}$ range of 5-10. The buffers used were: $0.1 \mathrm{M} \mathrm{CH}_{3} \mathrm{COOH}-\mathrm{CH}_{3} \mathrm{COONa}$ (pHs 5.0, 5.5, 6.0), $0.1 \mathrm{M} \mathrm{NaH}_{2} \mathrm{PO}_{4}-\mathrm{Na}_{2} \mathrm{HPO}_{4}$ (pHs 6.0, 6.5, 7.0, 7.5), 0.1 M Tris- $\mathrm{HCl}$ (pHs 7.5, 8.0, 8.5, 9.0), and 0.1 $\mathrm{M}$ glycine- $\mathrm{NaOH}$ (pHs 9.0, 9.5, 10.0). MnSOD47 activity was determined as the percentage residual activity relative to that of the control. The optimum temperature was analyzed in the range of $25-80{ }^{\circ} \mathrm{C}$ under standard conditions. 


\subsection{Thermostability}

The thermal stability of MnSOD47 was examined in the temperature range of $37-50{ }^{\circ} \mathrm{C}$. The enzyme was incubated in $0.1 \mathrm{M} \mathrm{NaH} \mathrm{PO}_{4}-\mathrm{Na}_{2} \mathrm{HPO}_{4}(\mathrm{pH}$ 7.5) buffer, and samples were removed at fixed time intervals. The reactions were allowed to cool on ice before the residual activity was determined under standard conditions. MnSOD47 activity was determined as the percentage residual activity relative to that of the control.

\subsection{Enzyme Inhibitors}

Final $10 \mathrm{mM}$ concentrations of chemical reagents such as $\mathrm{KCN}, \mathrm{H}_{2} \mathrm{O}_{2}$, and $\mathrm{NaN}_{3}$ were used as inhibitors of MnSOD activity. The enzyme was preincubated with each inhibitor at $\mathrm{pH} 7.5$ and $37{ }^{\circ} \mathrm{C}$ for $1 \mathrm{~h}$, before electrophoresis on a $12.5 \%$ native gel, to determine the MnSOD activity. The residual activity of each preincubated sample was measured using the NBT method for parallel comparisons [39].

\section{Conclusion}

In conclusion, we cloned the gene encoding MnSOD from Bacillus sp. MHS47 and characterized the recombinant MnSOD protein expressed in E. coli cells. The deduced amino acid sequence showed high identity (99\%) to the sequence of MnSOD from Bacillus cereus, and its biochemical properties are similar to those of other known MnSODs. Based on these sequence and biochemical analyses, we conclude that the putative MnSOD47 clone encodes a cellular MnSOD. This information on MnSOD47 may be useful in studies of the MnSODs of other thermotolerant microorganisms and in its biotechnological production. These data could be used to develop a biosensor for the detection of antioxidants and free radical activity. In the future, this basic knowledge could also be used to assess cancer risk in humans, and in therapeutic treatments.

\section{Acknowledgements}

We would like to thank the Office of the Higher Education Commission, Thailand for supporting by grant fund under the program Strategic Scholarships for Frontier Research Network for the Join Ph.D. Program Thai Doctoral degree for this research. We thank Srinakharinwirot research budget of Fiscal year 2008 (grant number 316/2551).

\section{References}

1. Fridovich, I. Superoxide dismutases: Defence against endogenous superoxide radical. Ciba Found. Symp. 1978, 65, 77-93.

2. Lavelle, F.; Michelson, A.M.; Dimitrijevic, L. Biological protection by superoxide dismutase. Biochem. Biophys. Res. Commun. 1973, 55, 350-357.

3. Paschen, W.; Weser, U. Letter: Singlet oxygen decontaminating activity of erythrocuprein (superoxide dismutase). Biochim. Biophys. Acta 1973, 327, 217-222.

4. Petkau, A.; Chelack, W.S.; Pleskach, S.D.; Meeker, B.E.; Brady, C.M. Radioprotection of mice by superoxide dismutase. Biochem. Biophys. Res. Commun. 1975, 65, 886-893. 
5. Fridovich, I. Superoxide radical and superoxide dismutases. Annu. Rev. Biochem. 1995, 64, 97-112.

6. Hassan, H.M. Superoxide dismutases. Ciba Found. Symp. 1980, 79, 125-142.

7. Angelova, M.; Dolashka-Angelova, P.; Ivanova, E.; Serkedjieva, J.; Slokoska, L.; Pashova, S.; Toshkova, R.; Vassilev, S.; Simeonov, I.; Hartmann, H.J.; Stoeva, S.; Weser, U.; Voelter, W. A novel glycosylated $\mathrm{Cu} / \mathrm{Zn}$-containing superoxide dismutase: Production and potential therapeutic effect. Microbiology 2001, 147, 1641-1650.

8. Farrow, K.N.; Lakshminrusimha, S.; Reda, W.J.; Wedgwood, S.; Czech, L.; Gugino, S.F.; Davis, J.M.; Russell, J.A.; Steinhorn, R.H. Superoxide dismutase restores eNOS expression and function in resistance pulmonary arteries from neonatal lambs with persistent pulmonary hypertension. Am. J. Physiol. Lung Cell Mol. Physiol. 2008, 295, L979-L987.

9. Kakimoto, K.; Kojima, Y.; Ishii, K.; Onoue, K.; Maeda, H. The suppressive effect of gelatin-conjugated superoxide dismutase on disease development and severity of collagen-induced arthritis in mice. Clin. Exp. Immunol. 1993, 94, 241-246.

10. Laurila, J.P.; Castellone, M.D.; Curcio, A.; Laatikainen, L.E.; Haaparanta-Solin, M.; Gronroos, T.J.; Marjamaki, P.; Martikainen, S.; Santoro, M.; Laukkanen, M.O. Extracellular superoxide dismutase is a growth regulatory mediator of tissue injury recovery. Mol. Ther. 2009, 17, 448-454.

11. Mates, J.M.; Sanchez-Jimenez, F.M. Role of reactive oxygen species in apoptosis: Implications for cancer therapy. Int. J. Biochem. Cell Biol. 2000, 32, 157-170.

12. Rios, L.; Cluzel, J.; Vennat, J.C.; Menerath, J.M.; Doly, M. Comparison of intraocular treatment of DMTU and SOD following retinal ischemia in rats. J. Ocul. Pharmacol. Ther. 1999, 15, $547-556$.

13. Teoh, M.L.; Fitzgerald, M.P.; Oberley, L.W.; Domann, F.E. Overexpression of extracellular superoxide dismutase attenuates heparanase expression and inhibits breast carcinoma cell growth and invasion. Cancer Res. 2009, 69, 6355-6363.

14. Trotti, A. Toxicity antagonists in cancer therapy. Curr. Opin. Oncol. 1997, 9, 569-578.

15. Yunoki, M.; Kawauchi, M.; Ukita, N.; Noguchi, Y.; Nishio, S.; Ono, Y.; Asari, S.; Ohmoto, T.; Asanuma, M.; Ogawa, N. Effects of lecithinized superoxide dismutase on traumatic brain injury in rats. J. Neurotrauma 1997, 14, 739-746.

16. Zemlyak, I.; Nimon, V.; Brooke, S.; Moore, T.; McLaughlin, J.; Sapolsky, R. Gene therapy in the nervous system with superoxide dismutase. Brain Res. 2006, 1088, 12-18.

17. Zhong, W.; Oberley, L.W.; Oberley, T.D.; St Clair, D.K. Suppression of the malignant phenotype of human glioma cells by overexpression of manganese superoxide dismutase. Oncogene 1997, 14, 481-490.

18. Emregul, E. Development of a new biosensor for superoxide radicals. Anal. Bioanal. Chem. 2005, 383, 947-954.

19. Li, D.C.; Gao, J.; Li, Y.L.; Lu, J. A thermostable manganese-containing superoxide dismutase from the thermophilic fungus Thermomyces lanuginosus. Extremophiles 2005, 9, 1-6.

20. Amo, T.; Atomi, H.; Imanaka, T. Biochemical properties and regulated gene expression of the superoxide dismutase from the facultatively aerobic hyperthermophile Pyrobaculum calidifontis. J. Bacteriol. 2003, 185, 6340-6347. 
21. Lim, J.H.; Yu, Y.G.; Han, Y.S.; Cho, S.; Ahn, B.Y.; Kim, S.H.; Cho, Y. The crystal structure of an Fe-superoxide dismutase from the hyperthermophile Aquifex pyrophilus at 1.9 A resolution: structural basis for thermostability. J. Mol. Biol. 1997, 270, 259-274.

22. Seatovic, S.; Gligic, L.; Radulovic, Z.; Jankov, R.M. Purification and partial characterization of superoxide dismutase from the thermophilic bacteria Thermothrix sp. J. Serb. Chem. Soc. 2004, 69, 9-16.

23. Ursby, T.; Adinolfi, B.S.; Al-Karadaghi, S.; de Vendittis, E.; Bocchini, V. Iron superoxide dismutase from the archaeon Sulfolobus solfataricus: Analysis of structure and thermostability. J. Mol. Biol. 1999, 286, 189-205.

24. Wang, X.; Yang, H.; Ruan, L.; Liu, X.; Li, F.; Xu, X. Cloning and characterization of a thermostable superoxide dismutase from the thermophilic bacterium Rhodothermus sp. XMH10. J. Ind. Microbiol. Biotechnol. 2008, 35, 133-139.

25. Whittaker, M.M.; Whittaker, J.W. Recombinant superoxide dismutase from a hyperthermophilic archaeon, Pyrobaculum aerophilium. J. Biol. Inorg. Chem. 2000, 5, 402-408.

26. Whittaker, M.M.; Whittaker, J.W. A glutamate bridge is essential for dimer stability and metal selectivity in manganese superoxide dismutase. J. Biol. Chem. 1998, 273, 22188-22193.

27. Cheng, W.; Tung, Y.H.; Chiou, T.T.; Chen, J.C. Cloning and characterisation of mitochondrial manganese superoxide dismutase (mtMnSOD) from the giant freshwater prawn Macrobrachium rosenbergii. Fish Shellfish Immunol. 2006, 21, 453-466.

28. Graeff-Wohlleben, H.; Killat, S.; Banemann, A.; Guiso, N.; Gross, R. Cloning and characterization of an Mn-containing superoxide dismutase (SodA) of Bordetella pertussis. J. Bacteriol. 1997, 179, 2194-2201.

29. Parker, M.W.; Blake, C.C. Iron- and manganese-containing superoxide dismutases can be distinguished by analysis of their primary structures. FEBS Lett. 1988, 229, 377-382.

30. Babitha, M.P.; Prakash, H.S.; Shekar, S.H. Purification and partial characterization of manganese superoxide dismutase from downy mildew resistant pearl millet seedlings inoculated with Sclerospora graminicola. Plant Sci. 2002, 163, 917-924.

31. Ekanayake, P.M.; Kang, H.S.; de Zyosa, M.; Jee, Y.; Lee, Y.H.; Lee, J. Molecular cloning and characterization of Mn-superoxide dismutase from disk abalone (Haliotis discus discus). Comp. Biochem. Physiol. B Biochem. Mol. Biol. 2006, 145, 318-324.

32. Lan, X.; Zhang, X.; Hu, J.; Shimosaka, M. Cloning, expression, and characterization of a chitinase from the chitinolytic bacterium Aeromonas hydrophila strain SUWA-9. Biosci. Biotechnol. Biochem. 2006, 70, 2437-2442.

33. Motoshima, H.; Minagawa, E.; Tsukasaki, F.; Kaminogawa, S. Cloning and nucleotide sequencing of genes encoding Mn-superoxide dismutase and class II fumarase from Thermus aquaticus YT-1. J. Ferment. Bioeng.1998, 86, 21-27.

34. Ken, C.F.; Lee, C.C.; Duan, K.J.; Lin, C.T. Unusual stability of manganese superoxide dismutase from a new species, Tatumella ptyseos ct: Its gene structure, expression, and enzyme properties. Protein Expr. Purif. 2005, 40, 42-50.

35. Misra, H.P.; Fridovich, I. Inhibition of superoxide dismutases by azide. Arch. Biochem. Biophys. 1978, 189, 317-322. 
36. Song, N.N.; Zheng, Y.; E, S.J.; Li, D.C. Cloning, expression, and characterization of thermostable manganese superoxide dismutase from Thermoascus aurantiacus var. levisporus. J. Microbiol. 2009, 47, 123-130.

37. Ritalahti, K.M.; Loffler, F.E. Populations implicated in anaerobic reductive dechlorination of 1,2-dichloropropane in highly enriched bacterial communities. Appl. Environ. Microbiol. 2004, 70, 4088-4095.

38. Laemmli, U.K. Cleavage of structural proteins during the assembly of the head of bacteriophage T4. Nature 1970, 227, 680-685.

39. Beauchamp, C.; Fridovich, I. Superoxide dismutase: Improved assays and an assay applicable to acrylamide gels. Anal. Biochem. 1971, 44, 276-287.

(C) 2011 by the authors; licensee MDPI, Basel, Switzerland. This article is an open access article distributed under the terms and conditions of the Creative Commons Attribution license (http://creativecommons.org/licenses/by/3.0/). 